\title{
Correlation between the Evaluation of Knowledge, Attitudes Toward Social Science with Artificial Test the Quality of Elementary School Teachers in Ambon
}

\author{
Emma Rumahlewang, Jhoni Lagun Siang
}

\begin{abstract}
The objective of this research was to study the correlation berween evaluation knowledge, attitude on sosial studies and teachers made test quality. The population of this reserch was the junior hight schools students in Ambon City. The size of samples was 60 teacher, selected by multi stage random simple technique. The data were collected through questionnaires instruments to attitudes toward the Social Scinence and evaluation knowledge test while the quality of teacher-made tests are judged by five assessors for the validity of the content and results of the students' answers to subsequent empirical validity converted through the t-scores. The result concluded taht there was a positive correlation between (1) evaluation knowledge (X1) and teacher made test quality $(Y)$ with ry $1=0.79$ and $\hat{Y}=4,85+$ $0,57 X 1$. (2) there was positive correlation between attitude on social study $(X 2)$ and teacher made test quality $(Y)$ with ry2 $=0,79$ and $\hat{Y}=2,71+0,45 X 2$. (3) ther was positive correlation of evaluation knowledge (X1), attitude social study (X2) and teacher made test quality $(Y)$ with was shown by correlation coefficient Ry12 $=0,81$, and the equwtion of multiple linier regression $\hat{Y}=$ $1,28+0,27 X 1+1,26 X 2$. All the testing done at $\alpha=0,05$. Based on the results of this study, it was concluded that the evaluation of knowledge and attitudes towards ilmu pengetahuan sosial either separately or jointly positive effect on the quality of teacher-made tests. this means that the higher knowledge and more positive evaluation of the ilmu pengetahuan sosial, the quality test.
\end{abstract}

Index Terms: correlation evaluation of knowledge, attitudes, and artificial test Social Scinence.

\section{INTRODUCTION}

The institution in carrying out its functions always have expectations about the shape of the graduates produced at least have the knowledge, skills, and attitudes as a form of behavior change learning outcomes. Therefore, teachers as education are required to have a broad knowledge of evaluation and have mastered the subjects taught. Social science is one of the subjects taught at the Junior High School and became an important part in growing thoughts and change sisiwa about living in the same environment with life forms diversified, understand the interrelationship between one concept with another concept, between fakatu one with the other facts, between one principle with the other

Revised Manuscript Received on October 15, 2019.

Emma Rumahlewang, Departmen of Educational Universitas Pattimura Ambon, Jl. Ir. M. Putuhena, Poka-Ambon, ndonesia, 97233, Telp / Fax : 0911-322626, e.rumahlewang@ yahoo.co.id,

Jhoni Lagun Siang, Departmen of Matemathic Universitas Bumi Hijrah Maluku Utara, Sofifi, North Molucas, Indonesia, 97852, jhonilagunsiang@unibrah.ac.id. principles.

A teacher demanded professional, dynamic and creative, so that they can develop their potential and are able to develop and transform their students than not knowing to knowing. Am, a student is required awareness, readiness and willingness to accept and carry out the task well intrakurekuler, curricular and extracurricular. By carrying out this task, it will be reflected in ourselves teachers and students the optimal effort in order to achieve the expected learning outcomes. The extent of teacher and student learning outcomes to social science materials can be can be seen through the evaluation. Information obtained through these evaluations are turning unpan as well as a reference in improving and enhancing the learning process, so as to obtain maximum results. The evaluation is usually done through the provision of testing. The role of the test is quite influential in improving the quality of student learning, it occurred partly because the test provides information about the effectiveness of learning activities and will be used to improve the learning process. Given the evaluation is very important in decision-making, then the teachers as evaluators are required to have the ability and skill in choosing and designing an evaluation tool used. One of the evaluation tools are common and frequently used tests. Tests artificial social science teachers is a valid data source for assessing students' mastery of learning objectives, especially social science learning. Teacher-made test is one tool to get information about what we want to know. Thus the teachers are required to devise a test with good quality. A test if the quality is said to have a degree of validity and reliability is high. Teacher-made tests is meant a set of questions / grains of matter prepared by teachers. In general, teacher-made tests are not analyzed the level of validity and reliability, so that the possibility of errors in decision-making because the tests do not have the value of consistency and accuracy. in addition to the factor of teacher attitudes towards the subject matter also affects peroses and student learning outcomes. Thus, in this study the authors wanted to see the quality of teacher-made tests the validity and reliabilitanya associated with the evaluation of teachers' knowledge about and attitudes toward social science subjects. The problem research there is a relationship between teachers' knowledge about evaluation and attitude social science teachers to the quality of teacher-made tests? 


\section{Correlation between the Evaluation of Knowledge, Attitudes Toward Social Science With Artificial Test the Quality of Elementary School Teachers in Ambon}

The research objective was to determine the relationship between teachers' knowledge about evaluation and attitude towards the social sciences with the quality of teacher-made tests. In particular, this study aims to obtain information about (1) the relationship anatar teacher's knowledge of the evaluation of the quality of teacher-made tests, (2) the relationship anatara teacher attitudes toward the social sciences with the quality of teacher-made tests and (3) the relationship anatara teacher's knowledge of evaluation and attitudes toward social science teacher with the quality of teacher-made tests.develop educational interventions (about for example, learning processes, learning environments and the like) with the purpose to develop or validate theories.

\section{LITERATURE REVIEW}

\section{A. Learning}

Learning is a mental activity that cannot be observed from the outside, meaning that what happens in a person cannot be known directly only by observing that person. Learning according to Ormrod as quoted by Ratumanan (2012), is a long-term change in representation or mental association as a result of experience ((1).

Through learning it is hoped that changes will occur not only in cognitive aspects but also in psychomotor and affective aspects. Learning as stated by Slameto is "a process of business change carried out by someone to obtain a change in behavior as a whole, as a result of his own experience in his interaction with the environment (2)".

Shah revealed that "learning is a process that is a process and is a very fundamental element in the implementation of every type and level of education. The success of education is very dependent on the learning process at school and outside of school "(3).

Gagne also emphasizes the word change in terms of learning. According to Gagne, learning events can be identified by the occurrence of behavioral change and these changes take place continuously (persistent) (Gagne, 1975), which Nevid mentioned is relatively permanent change (5).

McKenzie said that:

Because learning is an ongoing process, both formative and summative methods of assessment must take place when addressing multiple intelligences through technology. Formative assessments are snapshots of time that allow teachers and students to check on progress in the process of learning (6).

Learning is an ongoing process to increase the chances of student success by examining each progress in the process through formative and summative assessment when a teacher handles the level of intelligence. Learning is not done in pieces but carried out continuously. To speed up success, the process that passes must be checked and then corrected until the goal is reached.

The National Research Council cited by the Board on Children, Youth, and Families (2004), reveals that: "Adjusting tasks to students 'skill levels are also important because learning is an active process, and learners' preexisting knowledge, skills, beliefs, and influence concepts how they make sense of new information ". School assignments must be tailored to students' skills because

learning is an active process of students and prior knowledge, skills, beliefs and previous concepts influence how they process to understand new information with their skill level (7)

Islamuddin revealed that "learning is of several types, namely abstract learning, learning skills, social learning, learning problem solving, rational learning, habit learning, appreciation learning, and learning knowledge" (8). Abstract learning is learning that uses abstract ways of thinking. The aim is to gain understanding and solving problems that are not real. Examples such as learning about religion or belief, art, metaphysics, etc.

Learning skills is learning by using motor movements, which are related to the nerves and muscles / neuromuscular. The aim is to acquire and master certain physical skills. Examples of learning are certain sports or games, workshops, household skills, etc.

Social learning is basically learning to understand social problems to solve problems. The aim is to master understanding and skills in solving social problems such as family problems, friendship problems, group problems and social issues. Learning problem solving is basically learning to use scientific methods or think systematically, logically, regularly, and thoroughly. The aim is to acquire the ability and cognitive skills to solve a problem rationally, straightforwardly, and thoroughly. Rational learning is learning by using the ability to think logically and rationally (according to a healthy mind). The aim is to obtain a variety of skills using principles and concepts.

\section{B. Atttitudes}

Ivor K. Davies explain knowledge is fundamental to skill and attitudes are frmly based on knowledge are strong and long-lasting. In the past, most people camed their livelihood as a resuld of the skils they possessed. Today, because of rapidly changing technologies, the knowledge workes is preeminent. The day of the manual worker has largely passed. (9). Lewis R. Aiken explain knowledge is justified true belief. The relevant sense of "justified" is the one we have expressed by means of the term "evident"; knowledge is evident true (10). Jack R Franklin \& Norman E Wallen clarify vadidity is the most important idea to consider when preparing or selecting an instrument for use (11). Fred N Kerlinger clarify reliability is the accuracy or precision of a measuring instrument (12). Based on theories and arguments raised by experts in the above it can be concluded. The test is a set of tools or instruments are collated and used to evaluate against an object. The instrument is expected to have a structured quality criteria. Quality is valid and reliabil because the instruments have a high validity and reliability will be able to measure that is to be measured accurately and reliably. Richard Cross clarify attitudes are "predispositions to respond to some class of stimuli with certain classes of response'. These classes of response are:

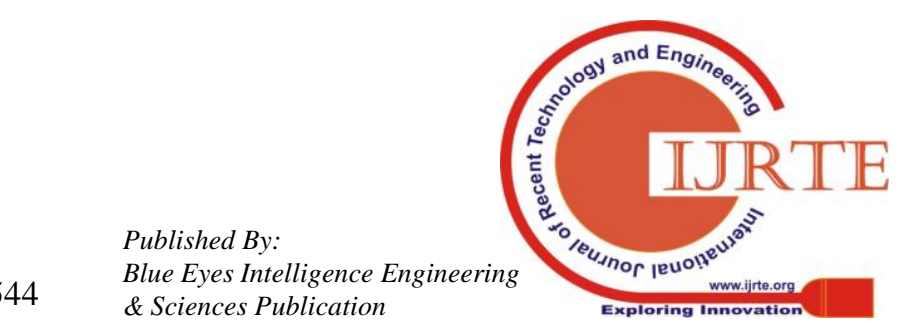


1. Affective: what a person feels about the attitude object, how favourably or unfavourably it is evaluated;

2. Cognitive: what a person believes the attitude object is like, objectively;

3. Behavioural: \{sometimes called the 'conative'\}: how a person actually responds, or intends to respond, to the attitude object based on $\{1\}$ and $\{2\}$ (13).

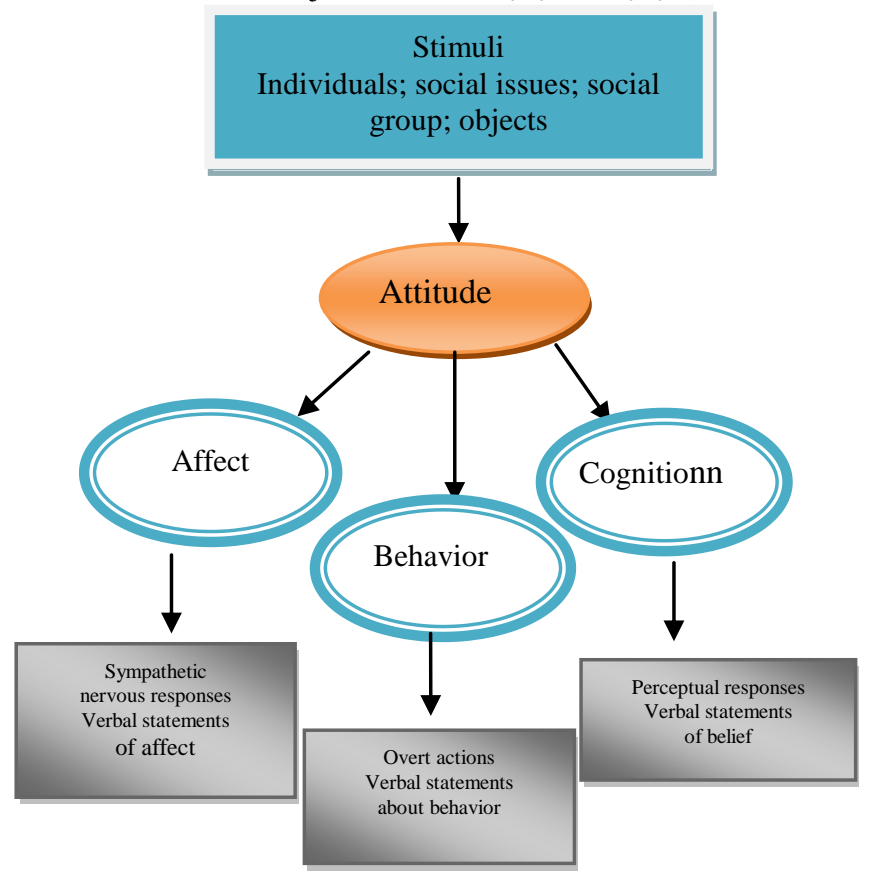

Fig 1. 1 The tripartite model of attitude structure (after Rosenberg and Hovland, 1960).

Based on theories and opinions expressed by the experts can disimpSikap an important thing that a person has to determine the assessment of an object and a view of a person against an object, because the attitude is also a keadan internal someone who is affected by the experience in families, communities, and the results teacher interaction with students in the learning process.

\section{METHODOLOGY/MATERIALS}

The objective of this research was to study the correlation berween evaluation knowledge, attitude on sosial studies and teachers made test quality. The population of this reserch was the junior hight schools students in Ambon City. The size of samples was 60 teacher, selected by multi stage random simple technique. The data were collected through questionnaires instruments to attitudes toward the Social Scinence and evaluation knowledge test while the quality of teacher-made tests are judged by five assessors for the validity of the content and results of the students' answers to subsequent empirical validity converted through the t-scores.

\section{RESULTS AND FINDINGS}

Based on the research results can be described as follows: (1) the quality of the test of social science teachers in komamadya Ambon artificial categorized high enough. This suggests to us that the quality of teacher-made tests in the municipality of Ambon meet quality standards Good test the validity have high reliability. It is characterized by the calculation of empirical validity and reliability with an average score of 50.10, and a standard deviation of 7.45. Variations of these data showed that $17(28.33 \%)$ obtained a score below the average, 13 people $(21.67 \%)$ are on the average and $30(50.33 \%)$ above the average. (2) the teacher's knowledge of the evaluation can be considered quite high. This is evident from the results of research that shows the average score of 79.38 and a standard deviation of 10.34 . Variation of the data showed that 18 people or $30 \%$ of respondents have knowledge evaluation score below the average score; 8 or 13:33\% of respondents in the group mean score and 34 people or $56.77 \%$ of respondents above the average score. Thus it can be said that the teacher's knowledge of evaluation that is owned by secondary school teachers in the Municipality of Ambon categorized high enough. This also gives an answer to us that most of the teachers' level of knowledge about the evaluation is quite high. (3) attitudes of teachers of the subject matter of social science shows the average score of 105.33, and a standard deviation of 11.74. Such data provide a picture for us that the attitude of teachers towards the Social Sciences is quite high. 24 or $40 \%$ had an average score, 15 or $25 \%$ in the group average score, below the average score there are 21 people or $35 \%$. This suggests to us that the attitude of the teachers of the subject matter of social science being.

Testing hypotheses using regression analysis and the simple correlation is seen that;

1) The first hypothesis in this study is that there is a positive correlation between teachers' knowledge about the evaluation of the quality of the tests made in social science teacher. From the calculation results obtained by $\mathrm{a}=4.85$ and $b=0: 57$. thus the price of $a d a b$ entering into the regression equation regression equation of $\mathrm{Y}$ on $\mathrm{X} 1$ is $\mathrm{Y}=4.85+$ $0.57 \mathrm{X} 1$. Based on test results obtained Fhitung linearity regression equation of 0.85 . While the distribution list $F$ with significance level $\alpha=0.05$ and degrees obtained Ftabel at $2: 03$. If we compare the two, it turns out Fhitung < Ftabel or $1: 49<2: 03$. It can be concluded that the regression equation $\mathrm{Y}=4.85+0.57 \mathrm{X} 1$ is Linear. After the linearity test, followed by a test of significance. Retrieved Fhitung $=96.12$. While the distribution list Ftabel at 4:01. When compared both turns Fhitung > Ftable or 96.12> 4:01. If it is associated with the testing criteria, then $\mathrm{Ho}$ is rejected and $\mathrm{H} 1$ accepted. It can be concluded that the regression coefficient $\beta$ is very significant. The next significant test of the correlation coefficient between pengentahuan evaluation (X1) with the quality of teacher-made tests $(\mathrm{Y})$ using the $\mathrm{t}$ test. From the analysis of simple correlation coefficient ry $1=0.79,8$ and the coefficient of determination $\mathrm{r} 2 \mathrm{y} 1=0.62$. This simple correlation coefficient is significant after diujib with $\mathrm{t}$ test. This is evidenced by thitung $>$ ttabel or $9.71>1.67$ at the level of $\alpha=$ 0.05 and degrees of freedom 58 . The relationship between the teacher's knowledge about the evaluation of the quality tests partially tested by controlling attitude towards the social sciences from the calculation coefficient obtained ry1.2 = $0: 33$. and the coefficient of determination $\mathrm{r} 2 \mathrm{y} 1.2=0: 11$. 


\section{Correlation between the Evaluation of Knowledge, Attitudes Toward Social Science With Artificial Test the Quality of Elementary School Teachers in Ambon}

2) The second hypothesis in this study is that there is a positive correlation between attitudes towards social science teacher quality test. From the calculation obtained $\mathrm{a}=2.71$ and $b=0: 45$. thus the price of $a d a b$ entering into the regression equation regression equation of $\mathrm{Y}$ on $\mathrm{X} 2$ is $\mathrm{Y}=$ $2.71+0.45 \mathrm{X} 2$. Based on test results obtained linearity regression equation Fhitung 1.25. While the distribution list $\mathrm{F}$ with significance level $\alpha=0.05$ and by 1.87 degrees obtained Ftabel. If we compare the two, it turns out Fhitung < Ftabel or $1: 25<1.87$. It can be concluded that the regression equation $\mathrm{Y}=2.71+0.45 \mathrm{X} 2$ is Linear. After the linearity test, followed by a test of significance. Retrieved Fhitung $=96.42$. While the distribution list Ftabel at 4:01. When compared both turns Fhitung> Ftable or 96.42> 4:01. If it is associated with the testing criteria, then Ho is rejected and $\mathrm{H} 1$ accepted. It can be concluded that the regression coefficient $\beta$ is very significant. The next significant test correlation coefficients between teacher attitudes terhapap social sciences (X2) with the quality of teacher-made tests $(\mathrm{Y})$ using the $\mathrm{t}$ test. From the analysis of simple correlation coefficient ry $1=0.79,8$ and the coefficient of determination $\mathrm{r} 2 \mathrm{y} 1=0.62$. This simple correlation coefficient is significantly tested by $\mathrm{t}$ test. This is evidenced by thitung $>$ ttabel or 9.71 $>1.67$ at the level of $\alpha=$ 0.05 and degrees of freedom 58. The relationship between attitudes toward social science teacher quality tests partially tested by controlling the teacher's knowledge of the evaluation, the calculation coefficient obtained ry1.2 $=0: 33$. and the coefficient of determination $\mathrm{r} 2 \mathrm{y} 1.2=0: 11$.

(3) The third hypothesis in this study is that there is a positive correlation between teachers' knowledge about evaluation and teacher attitudes towards the social sciences with the quality of the test. By using multiple regression and correlation analysis through $\mathrm{Y}=\mathrm{a} 0+\mathrm{a} 1 \times 1+\mathrm{a} 2 \times 2$. From the calculation results obtained $\mathrm{a} 0=1.28$ and $\mathrm{a} 1=\mathrm{a} 2=0: 27$ and $0: 26$. by entering a price of $\mathrm{a} 0, \mathrm{a} 1 \mathrm{and} \mathrm{b} 2$ into the regression equation, the regression equation $\mathrm{Y}$ or $\mathrm{X} 1$ and $\mathrm{X} 2$ is $\mathrm{Y}=1.28$ $+0.26 \mathrm{X} 2.12$ to test the strength of the relationship X1 and X2 to $\mathrm{Y}$, linearity and significant test Multiple regression coefficient $\beta 1$ and $\beta 2$ by using the test statistic $F$. Based on the calculations, Fhitung 57.10. While the distribution list obtained sigifikan $\mathrm{F}$ with $\alpha=0.05$ Ftabel at 2:53. If we compare the two, it turns out Fhitung> Ftable or 57.10> 2:53. Thus, according to the test criteria, $\mathrm{H} 0$ and $\mathrm{H} 1$ means accept. This means, towards regression coefficients $\beta 1$ and $\beta 2$ is significant. After multiple regression coefficient significance test, followed by testing the multiple correlation between the variables knowledge of evaluation (X1) and attitude towards Social Scinence (X2) with the quality of teacher-made tests $(\mathrm{Y})$, using multiple correlation analysis. From the calculation of multiple correlation of 0.81 and Ry.12 R2y.12 determination coefficient of 0.66 . The next test multiple significance of the correlation coefficient using $\mathrm{F}$ test From the calculation of $\mathrm{F}=57.10$ and $\mathrm{F}$ table $=2.53$ at $\alpha$ $=0: 05$ Ftabel obtained at 2:53. When compared both turns Fhitung> Ftabel can thus be concluded that the correlation coefficient $\mathrm{n}$ is significant.

From the calculation obtained $a=2.71$ and $b=0: 45$. thus the price of $\mathrm{a} d \mathrm{da}$ entering into the regression equation regression equation of $\mathrm{Y}$ on $\mathrm{X} 2$ is $\mathrm{Y}=2.71+0.45 \mathrm{X} 2$. Based on test results obtained linearity regression equation Fhitung
1.25. While the distribution list $\mathrm{F}$ with significance level $\alpha=$ 0.05 and by 1.87 degrees obtained Ftabel. If we compare the two, it turns out Fhitung <Ftabel or 1:25<1.87. It can be concluded that the regression equation $\mathrm{Y}=2.71+0.45 \mathrm{X} 2$ is Linear. After the linearity test, followed by a test of significance. Retrieved Fhitung $=96.42$. While the distribution list Ftabel at 4:01. When compared both turns Fhitung> Ftable or 96.42> 4:01. If it is associated with the testing criteria, then Ho is rejected and $\mathrm{H} 1$ accepted. It can be concluded that the regression coefficient $\beta$ is very significant.

After multiple regression coefficient significance test, followed by testing the multiple correlation between the variables knowledge of evaluation (X1) and attitude towards Social Scinence (X2) with the quality of teacher-made tests $(\mathrm{Y})$, using multiple correlation analysis. From the calculation of multiple correlation of 0.81 and Ry.12 R2y.12 determination coefficient of 0.66 . The next test multiple significance of the correlation coefficient using $\mathrm{F}$ test From the calculation of $\mathrm{F}=57.10$ and $\mathrm{F}$ table $=2.53$ at $\alpha=0: 05$ Ftabel obtained at 2:53. When compared both turns Fhitung> Ftabel can thus be concluded that the correlation coefficient $n$ is significant.

From the calculation obtained $a=2.71$ and $b=0: 45$. thus the price of $\mathrm{a} d \mathrm{da}$ entering into the regression equation regression equation of $\mathrm{Y}$ on $\mathrm{X} 2$ is $\mathrm{Y}=2.71+0.45 \mathrm{X} 2$. Based on test results obtained Fhitung linearity regression equation of 1.25. While the distribution list $\mathrm{F}$ with significance level $\alpha$ $=0.05$ and by 1.87 degrees obtained Ftabel. If we compare the two, it turns out Fhitung <Ftabel or 1:25<1.87. It can be concluded that the regression equation $\mathrm{Y}=2.71+0.45 \mathrm{X} 2$ is Linear.

From the calculation obtained $a=2.71$ and $b=0: 45$. thus the price of $\mathrm{a} d \mathrm{da}$ entering into the regression equation regression equation of $\mathrm{Y}$ on $\mathrm{X} 2$ is $\mathrm{Y}=2.71+0.45 \mathrm{X} 2$. Based on test results obtained Fhitung linearity regression equation of 1.25. While the distribution list $F$ with significance level $\alpha$ $=0.05$ and by 1.87 degrees obtained Ftabel. If we compare the two, it turns out Fhitung <Ftabel or 1:25<1.87. It can be concluded that the regression equation $\mathrm{Y}=2.71+0.45 \mathrm{X} 2$ is Linear.

The next significant test correlation coefficients between teacher attitudes terhapap social sciences (X2) with the quality of teacher-made tests $(\mathrm{Y})$ with using a t test. From the analysis of simple correlation coefficient ry $1=0.79,8$ and the coefficient of determination $\mathrm{r} 2 \mathrm{y} 1=0.62$. This simple correlation coefficient is significantly tested by $t$ test. This is evidenced by thitung > ttabel or 9.71>1.67 at the level of $\alpha=$ 0.05 and a degree of freedom 58. The relationship between attitudes toward social science teacher quality tests partially tested by controlling the teacher's knowledge of the evaluation, the calculation coefficient obtained ry1.2 $=0: 33$. and the coefficient of determination $\mathrm{r} 2 \mathrm{y} 1.2=0: 11$ 


\section{DISCUSSION}

The outcome score calculation validity and reliability scores were converted through T-Score and associated with the appropriate level of validity and reliability study of theory, then in general it can be said that the quality of teacher-made tests Social Scinence Ambon City high quality. The information above illustrate, that the quality of the tests relating to quality of test items. While the quality of the items related to the teacher's knowledge of evaluation and teacher attitudes towards Social Sciences. The relationship is supported by the results of research which states that there is a positive relationship between the teacher's knowledge about the evaluation of the quality of teacher-made tests that have been tested or significance at $\alpha=0: 05$. This is indicated by a correlation coefficient of 0.79 and rhitung ry $1=0.71>$ rtabel $=1.67$. In addition, the results indicated partial correlation coefficients ry.12 at $0: 33$ and rtabel $=2.65>$ rtabel $=1.67$. R2y.1 detrminasi coefficient of 0.62 and $r 2 y .12$ at $0: 11$. This provides information, that simply $62 \%$ variation occurs in the quality of teacher-made tests are determined by the teacher's knowledge of evaluation and partial information, that $11 \%$ variation occurs in the quality of teacher-made tests are determined by the teacher's knowledge of the evaluation of the condition variable attitudes toward social science controlled. The pattern of the relationship between these variables, expressed by linear regression equation $\mathrm{y}=4.85+$ 0:57 X1. Thus concluded that the better the teacher's knowledge of the evaluation, the quality tests were made. Conversely, the less well the teacher's knowledge of the evaluation, the less quality tests were made, and will ultimately have an impact on student learning outcomes. By having a good knowledge and koprehensip, and has Extensive knowledge of evaluation, it is assumed that the preparation of test items actually represent the range of material taught and cognitive aspects sesuaidengan measured. Likewise, the information or data captured through these tests give accurate learning outcomes in accordance with the purpose of teaching is expected.

Patterns of relationship attitudes toward social science teacher with a homemade quality tests have proven significantly in $\alpha: 0: 05$. This is indicated by a correlation coefficient of 0.79 ry 2 ; and rhitung $=2.65>$ rtabel $=1.67$. In addition, the results indicated partial correlation coefficients ry2.1 at $0: 33$ and rhitung $=2.65>$ rtabel $=1.67$. The coefficient of determination of 0.62 and $\mathrm{r} 2 \mathrm{y} 2.1 \mathrm{r} 2 \mathrm{y} 2$ at $0: 11$ to provide information, that simply $62 \%$ variation occurs in the quality of the test is determined by the attitude of teachers towards the social sciences. Partially provide information, that $11 \%$ variation occurs in the quality of the test is determined by the attitude of teachers towards the Social Sciences with kondiasi teacher's knowledge of the evaluation variables are controlled. The pattern of relationship between two variables, expressed by linear regression equation $\mathrm{y}=$ $2.71+0.45 \times 2$. Thus concluded that the more positive teacher attitudes toward social science, the tests were made also quality; or otherwise increasingly negative attitudes toward social science teacher, the less quality as well test made, which will ultimately have an impact on student learning outcomes. This is in line with Gagne said that attitude as a system on how a person evaluates something around it.

Knowledge and attitudes of teachers about the evaluation of teachers on social sciences together with links to the quality of teacher-made tests. This is evidenced by $\mathrm{F}$ count $>\mathrm{F}$ table or 57.10> 2:53, and Ry.12 at 0.81 and at $0.67 \mathrm{R} 2 \mathrm{y} 12$. The third relationship pattern shown by the variable multiple linear regression equation $y=1: 28+0.0 .27+0.26 \times 2$. This means that the better and comprehensive knowledge about evaluating teachers and more positive attitudes towards social science teacher, then the tests were made also quality; vice versa, the less comprehensively teacher's knowledge of evaluation and increasingly negative attitudes toward social science teacher, then the less quality tests made. R2y.12 determination coefficient of 0.67 , providing information that $67 \%$ variation occurs in the quality score Social Scinence tests determined jointly by the evaluation of knowledge and attitudes to Social Scinence through a functional relationship $\hat{\mathrm{Y}}=1.28+0.27 . \mathrm{X} 1+0.26 \mathrm{X} 2$ that have been tested or significance.

Knowledge and attitudes of teachers about the evaluation of teachers on social sciences together with links to the quality of teacher-made tests. This is evidenced by $\mathrm{F}$ count $>\mathrm{F}$ table or 57.10> 2:53, and Ry.12 at 0.81 and at $0.67 \mathrm{R} 2 \mathrm{y} 12$. The third relationship pattern shown by the variable multiple linear regression equation $y=1: 28+0.0 .27+0.26 \times 2$. This means that the better and comprehensive knowledge about evaluating teachers and more positive attitudes towards social science teacher, then the tests were made also quality; vice versa, the less comprehensively teacher's knowledge of evaluation and increasingly negative attitudes toward social science teacher, then the less quality tests made. R2y.12 determination coefficient of 0.67 , providing information that $67 \%$ variation occurs in the quality score Social Scinence tests determined jointly by the evaluation of knowledge and attitudes to Social Scinence through a functional relationship $\hat{\mathrm{Y}}=1.28+0.27 . \mathrm{X} 1+0.26 \mathrm{X} 2$ that have been tested or significance .

\section{CONCLUSION}

\section{A. Descriptive Analysis}

The first of the results of descriptive analysis, the quality level of junior high school teacher-made tests throughout the Municipality of Ambon at the high category. This is shown by the average scores for the quality of teacher-made tests 10.10.berdasarkan average scores, it is known that $21.67 \%$ teacher-made test scores are on average, $28.33 \%$ are in the score below average and $50.33 \%$ in the scores above average. Second, the descriptive analysis of the origin, the level of teacher knowledge about the evaluation of 79.33 Based on average scores, it is known that the 13:33\% teacher's knowledge of evaluation tests, are on average scores, $30 \%$ are in the score below average and $56.77 \%$ are at above-average scores. Third, the results of descriptive analysis, the attitude of teachers towards the social sciences in the municipality of Ambon at the high category.

\section{and Enging}

F

(n)
.

.

.

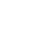

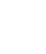

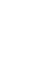




\section{Correlation between the Evaluation of Knowledge, Attitudes Toward Social Science With Artificial Test the Quality of Elementary School Teachers in Ambon}

This is evidenced by an average score of 105.33 teacher statement. Based on average scores, it is known that $35 \%$ of teachers attitudes toward social science scores are on average, $25 \%$ are in the score below the average and $40 \%$ are at above-average scores.

\section{B. Analysis Inferential}

First, there is a positive relationship between the teacher's knowledge about the evaluation of the quality of teacher-made tests. This conclusion gives the sense that the better a comprehensive knowledge of the teacher evaluation, the more quality tests were made. And vice versa, the less well the teacher's knowledge about the less quality evaluation test product.

Secondly, there is a positive relationship between the attitudes of teachers towards Advancement of social knowledge with the quality of teacher-made tests. This conclusion gives the sense that the more positive attitudes about social science teacher, the more quality tests were made. And vice versa, the negative attitudes of teachers of social sciences the less quality tests makes.

Third, there is a positive correlation between the quality of teacher-made tests to evaluate teachers' knowledge about and attitudes toward the social sciences. This conclusion gives the sense that the better and positive teacher's knowledge of the evaluation, the more quality tests were made. And vice versa, the less good and the negative attitudes of teachers towards the social sciences, the more less qualified test product.

From some of the above conclusion it can be said unequivocally that the teacher's knowledge of evaluation and teacher attitudes towards the social sciences is closely related to the quality of teacher-made tests.

\section{Implications}

In general, this research has concluded that there is a positive relationship between teachers' knowledge about evaluation and teacher attitudes towards the social sciences with the quality of teacher-made tests. From the conclusions of this study can be put forward several research implications both theoretically and practically.

1. The results of this study suggests there is a positive relationship between teachers' knowledge about evaluation and teacher-made tests.

The results also provide information that the teacher's knowledge of the evaluation arriving at a high level, so it has a very significant influence on the quality of teacher-made tests. From this fact can be interpreted that the absence of a qualified teacher-made tests is strongly influenced by the teacher's knowledge of the evaluation, which in turn have an impact on student learning outcomes scores.

2. The results of this study suggests there is a positive relationship between attitudes toward social science teacher quality tests buiatan teacher. This means teachers' attitudes towards science soial can improve the quality of teacher-made tests. Thus to improve the quality of teacher-made tests in order to be qualified again then there needs to be a change of attitude of teachers towards the social sciences field. Besides, this issue should be a concern for every teacher maker

of test not only for teachers who teach social science fields of study that the research samples to better address the subject areas they teach. The results also provide information nahwa teacher attitudes toward the social sciences are at a high level, so it has a very significant influence on the quality of teacher-made tests. From this fact can be interpreted that the absence of a qualified teacher-made tests is strongly influenced by the attitude of teachers towards the social sciences, which in turn have an impact on student learning outcomes scores.

3. The results of this study suggests there is a positive relationship between teachers' knowledge about evaluation and teacher attitudes towards the social sciences with the quality of teacher-made tests. This means poengetahuan teachers on teacher evaluation and attitude towards the social sciences can improve the quality of teacher-made tests. Thus to improve the quality of teacher-made tests in order to be qualified again it is necessary to increase teachers' knowledge about evaluation and increase positive attitudes towards social sciences.

These findings are expected to be a reference and motivation to re-examine and improve the weaknesses in determining the suitability of items with the material being taught, the instructional goals, as well as the language and construction. And to make it happen, need to increase teacher knowledge of evaluation such as: the concept of evaluation, the principles of evaluation, the types of evaluation, engineering or evaluation procedures, processing and interpretation of the results of the evaluation. Such improvements can dilakukann through upgrading-upgrading courses, workshops or training relating to the evaluation. The attitude can be done through the teacher's presence at meetings of teachers (MGMP), discussing with peers and seek information through reading books or internet support and others. Kolerasional relationship between the studied variables showed that the quality of teacher-made tests can be determined on the evaluation of teachers' knowledge and attitudes toward social science teacher. This is evidenced by mengujian done either separately or jointly. These findings provide the theoretical implications for teachers and instasi mone that the quality of teacher-made tests will rise better when teachers try to improve knowledge about evaluation and increase positive attitudes towards social sciences or disciplines.

\section{ACKNOWLEDGEMENTS}

This research work is supported by Faculty of Education Pattimura University. 


\section{REFERENCES}

1. Ratumanan TG. Belajar dan Pembelajaran Serta Faktor-Faktor Yang Mempengaruhinya. Yogyakarta: Unesa University Press; 2012. 2 p.

2. Slamento. Belajar dan faktor-faktor yang mempengaruhi. Jakarta: Rineka Cipta; 2010. 2 p

3. Syah M. Psikologi Pendidikan. Bandung: Remaja Rosdakarya; 2011. $171 \mathrm{p}$.

4. Robert M. Gagne LJB. The conditions of learning (United State of Amerika. The Dryden press; 1975. 6 p.

5. Nevid JS. Essentials of Psychology Concepts and Applications Third Edition. Wadsworth: Cengage Learning; 2012. 163 p.

6. McKenzie W. Multiple Intelligences and Instructional Technology. Washington: National Academy of Sciences; 2005. 152 p.

7. National Research Council. Committee on Increasing High School Students' Engagement and Motivation to Learn. Vol. 44. Washington: Washington: National Academy of Sciences; 2004.

8. Islamuddin H. Psikologi Pendidikan. Yogyakarta: Pustaka Pelajar; 2012. 169-173 p.

9. Davies IK. Instructional technique. New York: McMilan-Hill Book Company; 1981. $251 \mathrm{p}$.

10. Aiken LR. Psychological Testing and Assessment. Boston: Allyn and Bacon, Inc; 1997. 11 p.

11. Wallen JRF\& NE. Haw To Design and Evaluate Research In Education. New York: McGraw-Hill, Inc; 1993. 139 p.

12. Kerlinger FN. Foundation of Behavioral Research. New York: College Publishing; 1986. 405 p.

13. Cross R. Psychology The Science of Mind and Behaviour. London: Hodder and Atoughton; 1996. 434 p.

\section{AUTHORS PROFILE}

I am Emma Rumahlewang, currently affiliated with Departmen of Educational Universitas Pattimura Ambon, area of interest is education .my Jl. Ir. M. Putuhena, Poka-Ambon, ndonesia, 97233, Telp / Fax : 0911-322626, e.rumahlewang@yahoo.co.id,

My name is Jhoni Lagun Siang, affiliated with Departmen of Matemathic Universitas Bumi Hijrah Maluku Utara, Sofifi, North Molucas, Indonesia, 97852, jhonilagunsiang@unibrah.ac.id. 